\title{
展 望・解説
}

\section{LE-5 ロケットエンジンの開発についで*}

藤 村 威 明**

\author{
Development of the LE-5 Rocket Engine
}

\section{Takeaki FUJIMURA}

\section{1. まえがき}

昭和61年 8 月に初号機が打上げられた H- I 口 ケットの第 2 段に使われている LE-5 ロケットエ ンジンは, 液体酸素, 液体水素を推進薬とするも のとしてはわが国最初のロケットェンジンであ る。このエンジンは昭和 52 年から 60 年の間に開発 されたやや旧聞に属するエンジンであるが，ある いは何かのご参考になるかと思い，エンジン開発 において燃焼系と全体とりまとめを担当した三菱 重工の立場からみた開発経過をご紹介する。

\section{2. エンジン概要}

わが国の実用衛星打上げ用ロケットは，宇宙開 発事業団を中心に図 1 亿示すような機種が開発さ れてきた。 N-I 型ロケットは米国の Delta ロケ

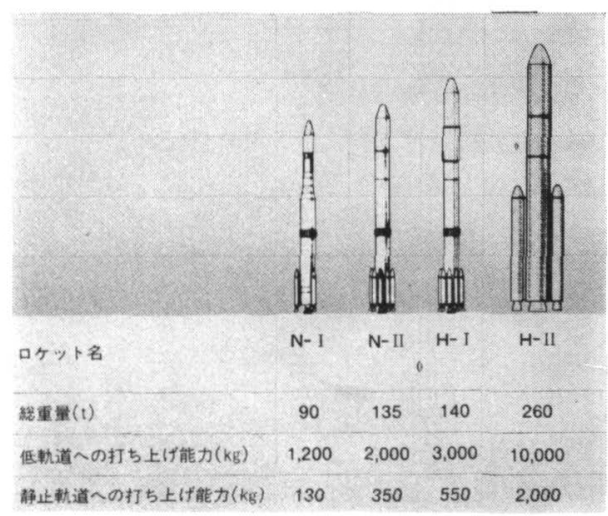

図 1 わが国の実用衛星打上げ用ロケット

*原稿受付 1989 年 1 月 9 日, 流机の可視化学会名古屋講演会 特別講演より

**三菱重工業㑣名古屋航空機製作所
ットを基にしたもので，第 2 段の LE-3 エンジン は米国の技術支援を受けながらわが国で開発され た最初の実用液体ロケットェンジンである。NII 口ケットの第 2 段には米国製のエンジンが使わ れたが， H-I ロケットはこの第 2 段を液体酸素, 液体水素を推進薬とする高性能の LE-5 エンジン で置き換えたものである。

液体酸素/液体水素ロケットェンジンとしては 米国の J-2, RL-10, SSME, 欧州の HM-7 等が あるが，これらェンジンの比推力は図 2 のように なり，LE-5 は RL-10，HM-7 等の上段用エンジ ンよりもひとまわり推力が大きく，高比推力とな っている。

LE-5 エンジンの諸元を表 1, 外観を図 3, 系 統図を図 4 亿示す。このエンジンはガスジェネレ ータサイクルのターボポンプ式ロケットエンジン で，ガスジェネレータで発生する約 $550^{\circ} \mathrm{C}$ の燃 焼ガスでターボポンプを駆動する。始動の際は, 始めに, タンク圧によって液体酸素, 液体水素が 供給され，燃焼室の壁を冷却して約 $130 \mathrm{~K}$ まで温

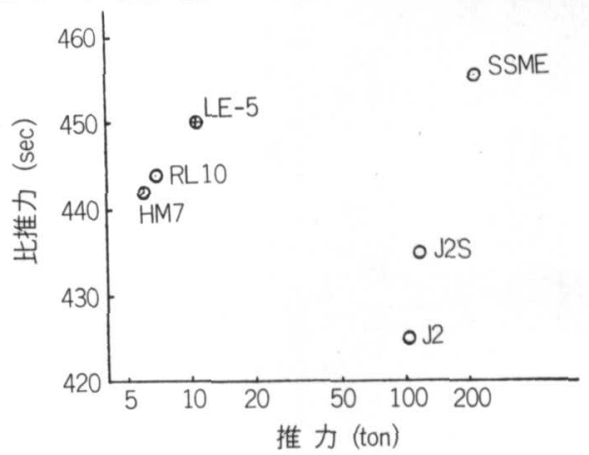

図 2 液体酸素/液体水素エンジンの性能 
表 1 LE-5 エンジン諸元

\begin{tabular}{|c|c|c|c|}
\hline \multicolumn{2}{|l|}{ 形 } & 式 & $\begin{array}{l}\text { ターポポンプ式再生 } \\
\text { 冷却液口エンジン }\end{array}$ \\
\hline 推 & \multirow[t]{2}{*}{ 進 } & 薬 & $\mathrm{LOX} / \mathrm{LH}_{2}$ \\
\hline 推 & & 力 & 10.5 ton \\
\hline 比 & 推 & 力 & $450 \mathrm{sec}$ \\
\hline 混 & 合 & 比 & 5.5 \\
\hline 燃 & 焼 & 圧 & $37 \mathrm{~kg} / \mathrm{cm}^{2} \mathrm{abs}$ \\
\hline \multicolumn{3}{|c|}{ ノズル膨張比 } & 140 \\
\hline 重 & & 量 & $255 \mathrm{~kg}$ \\
\hline 全 & & 長 & (ジシパル点より) \\
\hline 最 & 大 & 径 & $1634 \mathrm{~mm}$ \\
\hline
\end{tabular}

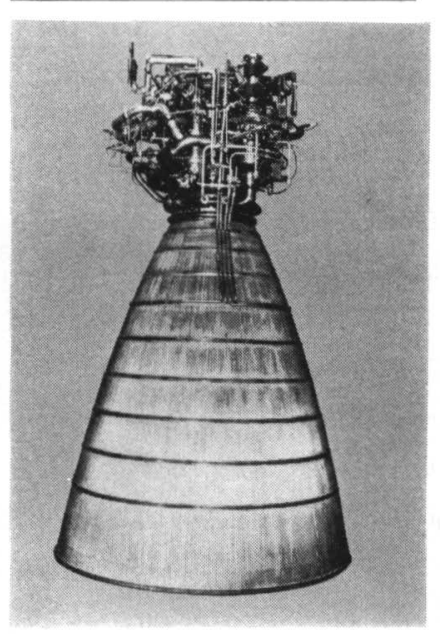

図 3 LE-5 エンジン

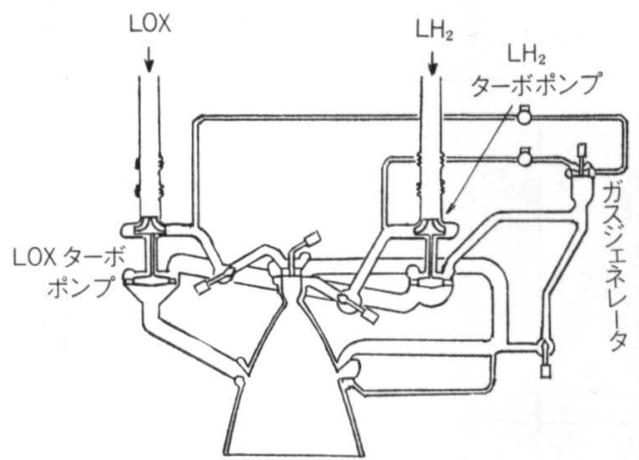

図 4 LE-5 エンジン系統図

度の上がった水素ガスによってターボポンプを駆 動するエクスパンダブリードサイクルで然焼室の 圧力を約 $75 \%$ まで上げたあと，ガスジェネレータ に点火してガスジェネレータサイクルに移行す る。

\section{3. 開発計画}

三菱重工では N-I 型ロケットの開発が始まっ た直後の昭和46年から, 次の世代の高性能ェンジ ンとしての液体酸素/液体水素エンジンに着目し
表 2 LE-5 開発当初予想した技術的な諸問題

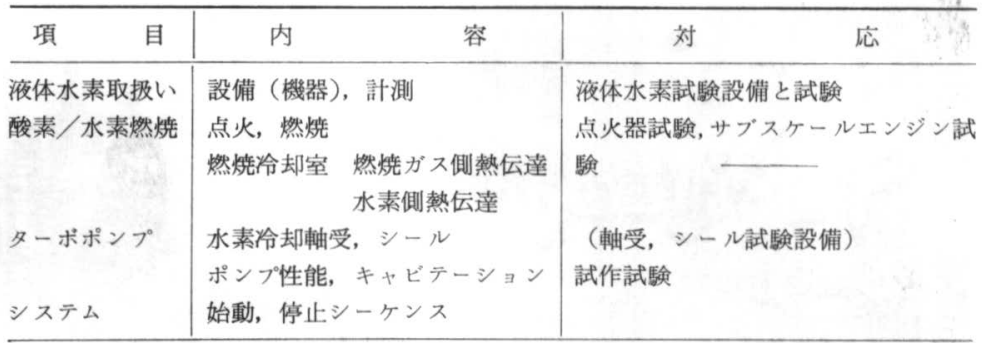

調査研究を開始した。この結果から LE-5 エンジ ンの開発に際して解決しなければならないと予想 した技術的問題点を抽出して先行的な研究を行っ た。この主なものを表 2 に示すが，この中で社内 で試験をしなかったのは燃燒室壁冷却のための管 内熱伝達である。このため, 開発段階に入ってか ら, 後述するよらに, 問題を起こすことになった といえなくもない。

社内に $20 l / \mathrm{H}$ の水素液化機を含む液体水素試 験設備を作ったのは昭和50年である。これを用い て液体水素の基礎的な試験や点火器の試験を開始 した。

昭和51年には, 秋田県田代町にロケット燃焼試 験場を開設し, 推力 $400 \mathrm{~kg}$ クラスの小型エンジ ンを用いた燃焼試験を開始した。この頃, これら の試験のための小型の液体水素試験装置を 3 基設 計・製作し自ら使用するといら経験ができたこと は, それ以後の大型の試験設備を建設し, 燃焼試 験を大きな不具合なく進める上で有効であった。

この前後に, 先行的に試作し試験したコンポー ネントはつぎのようなものである。

1) 点火器

2) サブスケールェンジン

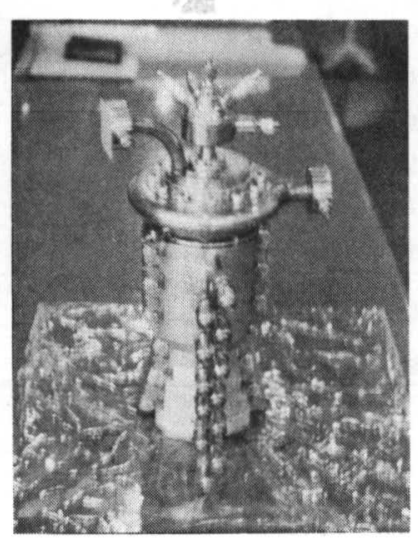

図 5 サブスケールエ ンジン 


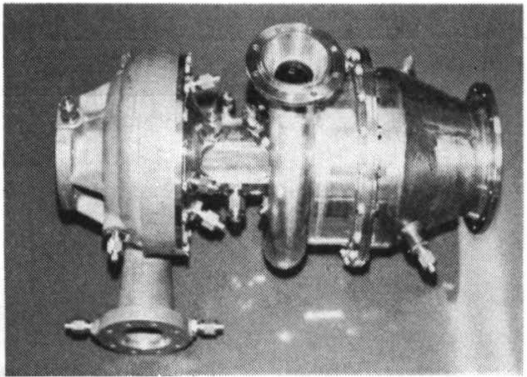

図 6 液体水 素ターボポ ンプ（社内 試作品）

液体酸素／液体水素エンジンの燃焼は液体酸 素とガス水素の燃焼である。酸素と水素を噴 射するインジェクタには, 多数の噴射ェレメ ントがあり，それぞれ中央の穴から液体酸素 を, それを包むように環状の口からガス水素 を酸素の約 20 倍の速度で噴射し, その剪断流 によって酸素を微粒化, 混合し, 燃焼させ る。この燃焼特性を調べるために, 実機の約 $1 / 25$ の推力のサブスケールェンジンを試作 し, 燃焼試験を実施した。なお, 同時に燃焼 室壁に伝わる熱量を測定するために, 燃焼室 は銅製の水冷式とした。

3) 液体水素ターボポソプ（図 6)

4 ) 液体酸素ターボポソプ（図 7)

これらの成果も取り入れて, 開発が本格化した

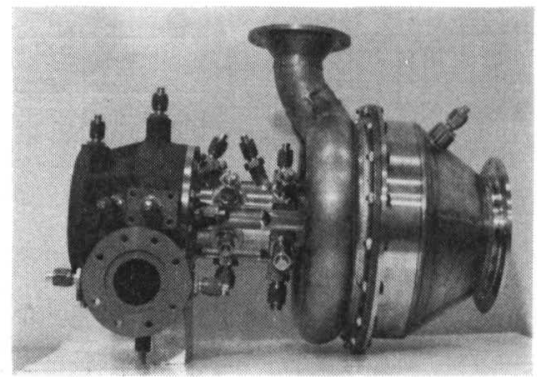

図 7 液体酸 素ターポポ ンプ（社内 試作品)

昭和52年頃に作った開発スケジュールを図式化し たものを図 8 に示す。なお，図中の供給系の開発 は石川島播麿重工業が担当した。

\section{4. 開発過程と主な技術的問題}

\section{1 水冷却燃焼室試験}

燃焼系の特性を把握するために, 図 9 に示すよ らな水冷却ェンジンを試作して, 昭和 53 年から燃 焼試験を実施した。水冷却燃焼室は, 燃焼ガスか ら燃燒室壁面に伝わる熱量をはかるためのもの で，無酸素銅製のリングに水の流れる溝を加工し たものを23個軸方向に積み重ねてろら付けし, 燃 焼室を形成したものである。水は周方向の適当な 位置からそれぞれの溝に入り，二つに分かれて周 方向に流孔たあと $180^{\circ}$ 反対の位置から外に出る。

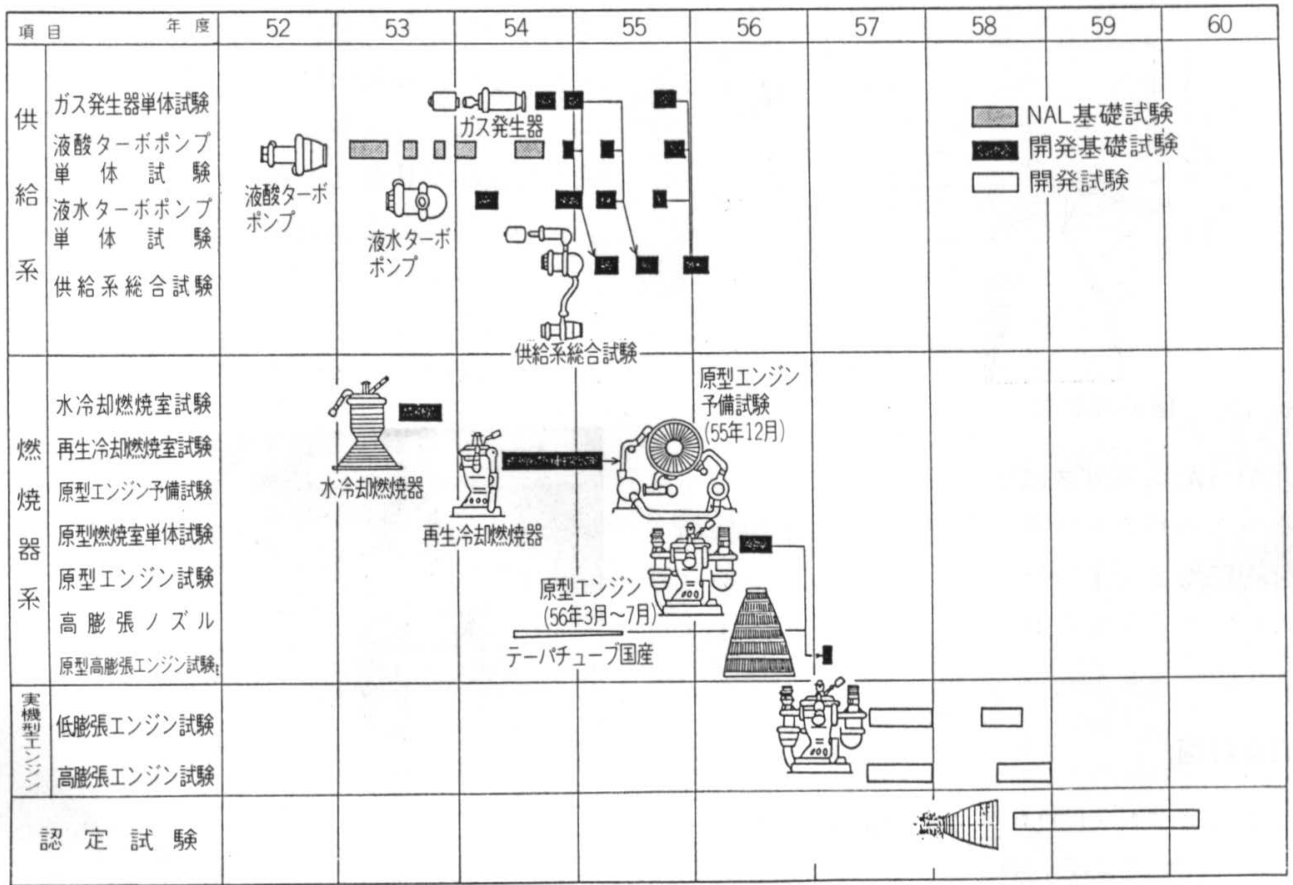

図8 LE-5 5 エンジン開発スケジュール 


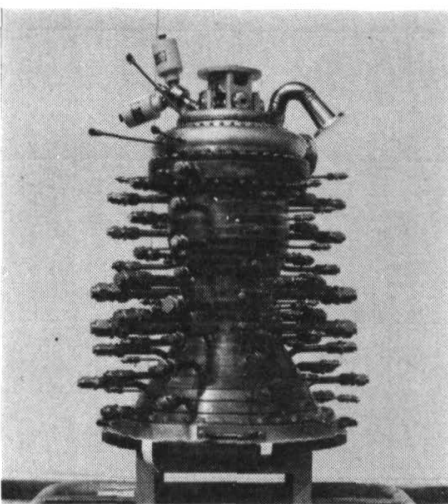

図 9 水冷却エンジン

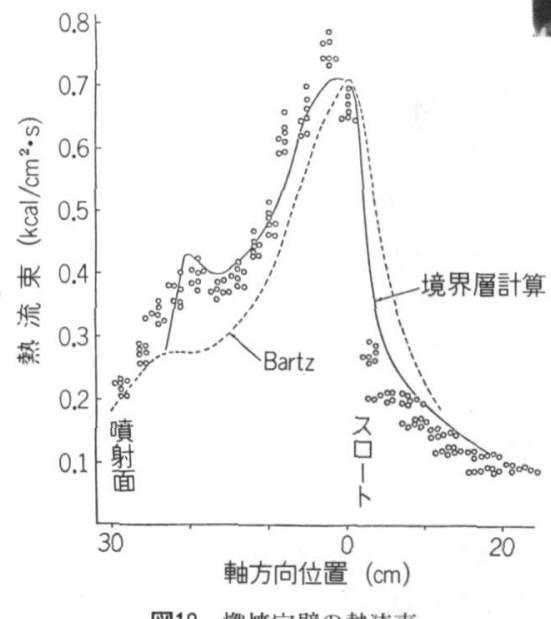

図10 燃焼室壁の熱流束

この水の入口, 出口の温度差と流量から熱流束が わかる。熱流束の計算には Bartz の式と境界層 計算によって求める式とがある。実測の結果は境 界層計算とよく一致している。図10はフィルム冷 却のない場合であり, フィルム冷却があるとこれ よりも下がるが，それは設計上の余裕と考学，こ れを基に再生冷却燃焼室の設計を行った。

燃焼室の伝熱量の測定と同時に，2種類のイン ジェクタを用いて比較燃焼試験を行い, 噴射ェレ メントの数の多い方が燃焼効率が高いことを確認 してこれを採用した。

\section{2 再生冷却燃焼室試験}

再生冷却燃燒室は水素を冷却剂として壁面を冷 却するもので，約240本の A286製のチューブを 燃焼室壁の形に成形して，ステンレス鋼製の内面 に並べてろら付けして燃焼室を形成するものであ る。チェーブは肉厚 $0.3 \mathrm{~mm}$, インジェクタ端直 径約 $3.2 \mathrm{~mm}$, スロート付近で幅 $1.8 \mathrm{~mm}$ の長 円

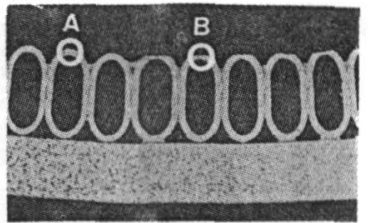

(a)
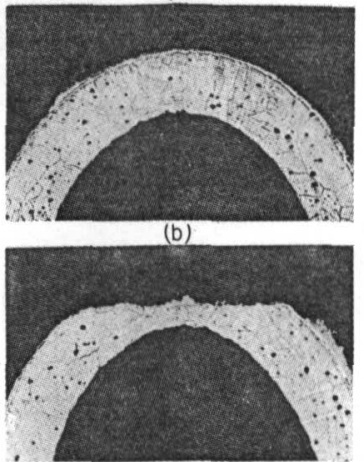

(c)

図12 燃焼室チューブ焼損部

形, ノズル出口部で直径約 $5.2 \mathrm{~mm}$ のダブルテー パ管である。水素はインジェクタ側から入って, ズル出口部に向かって流れる。この間に水素は熱 を吸収して温度は $28 \mathrm{~K}$ から約 $130 \mathrm{~K}$ に上昇する。

この再生冷却燃焼室を組み込んだェンジンの燃 焼試験は昭和54年 7 月から始まったが，スロート の少し上流で図11に示すようにチューブの頂部が 燒損し，その酸化物が下流部に付着して変色する といら不具合が発生した。焼損部の断面を図12に 示す。原因は冷却不足のためにチューブの温度が 上がり頂部が材料の燃焼温度に達したためと推定 されたので，局部的な高温を下げるために，チュ 一ブの頂部を平らにすることも試みたが解決しな かった。しかし，最終的にはチュープの材料を A-286 にくらべて熱伝導率が 4 倍の Ni に変更し てチューブ外面温度を約 $200^{\circ} \mathrm{C}$ 下げることによ って解決することができた。

\section{3 エンジンシステム}

前項までの試験は, ターボポンプを使わず, 液 体酸素と液体水素を高圧のタンクから燃燒室に供 給していた。実機ではターボポンプで酸素, 水素 を昇圧して燃焼室に供給するが，この燃焼系と夕 一ボポンプ系のマッチングはロケットェンジン開 発の中で難関の一つである。2 項で説明したよう に, LE- 5 エンジンの始動は, 最初, 低圧のタン クから供給される液体水素をポンプを通ったあと 


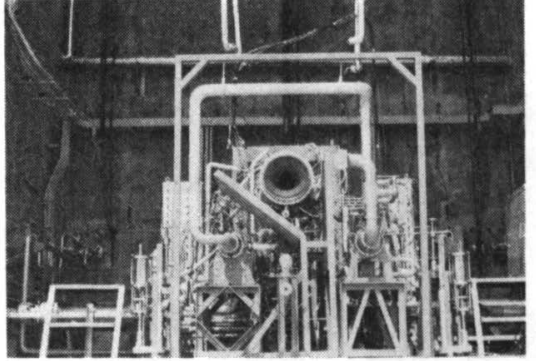

図13 原型エンジン予備試験

燃焼室壁で加熱してガス化させ，これでターボポ ンプを駆動するエクスパンダ・ブリードサイクル で定格出力の約 $75 \%$ まで立上げたあと，ガスジェ ネレータに点火してガスジェネレータサイクルに 移行する方式である。この技術的な問 題として は,

(1) ターボポンプの予泠

(2) タンクヘッドスタート方式の実証

(3) 高圧下でのガスジェネレータの点火

(4) エクスパンダ・ブリードサイクルからガスジ

ェネレータサイクルへの切換古

等がある。このため，図13に示すように燃焼系と ターボポンプ系を別々に据光付けて，これらを配 管でつないだ姿で原型エンジン予備試験と称して マッチング試験を実施した。この試験ではガスジ ェネレータへ供給する液体水素, 液体酸素配管の 断熱不足に起因する着火遅れや爆然，ガスジェネ レータ内部の氷結などを経験したが,

・26回目に 370 秒のエクスパンダ・ブリードサイ クルでの燃焼試験

・36回目に40秒のガスジェネレータサイクルでの 燃焼試験

にこぎつけることができた。

\section{4 高膨張エンジン試験}

LE-5 エンジンは，H-I ロケットの第 2 段に搭 載され，高度約 $100 \mathrm{~km}$ で作動を開始する。この 状態での作動特性と性能を確認するための試験は 昭和57年から宇宙開発事業団角田ロケット開発七 ンタの高空燃焼試験設備を使って実施された。こ の設備は 2 段の蒸気エジェクタを使って，エンジ ン停止中は 15 Torr, エンジン作動中 6 Torr に減 圧するもので，これによって，ノズルスカートを 取り付けた高膨張ェンジンの性能および耐久性を

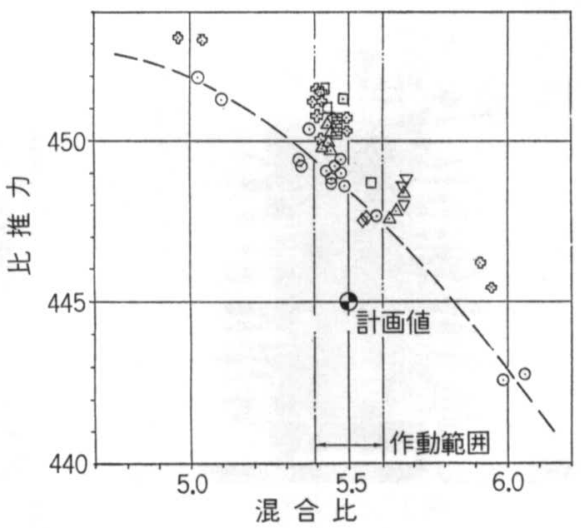

図14 LE-5 エンジン性能

確認した。図14に高膨張エンジンの性能を示す。

\section{5 再着火}

H- I ロケットのミッションによっては, LE-5 エンジンの再着火が必要になる。このときに予想 される問題としては,

(1) 第 1 回の燃焼終了後, ターボポンプのタービ ンからポンプ側への伝熱によるポンプの温度 上昇（予冷不足）

（2）ガスジェネレータや主燃焼室で，燃焼によっ て生成した水分が燃焼終了後インジェクタ等 に氷結し，次の燃焼に支障を与える（地上の 大気圧燃焼試験では, 停止時に付着した氷は 長時間窒素ガス等でパージをしないと除去で きない)。

（3）酸素，水素が液状でェンジンに供給できるか 等である。前 2 項については高空燃焼試験設備を 用いて $300 \sim 1800$ 秒の間隔を扣いて 2 回の燃焼試 験を行い問題のないことを確認した。(3)は再着火 のために数\%しか残っていない液体酸素と液体酸 素を無重力状態でタンクの底に集めて，ガスを吸 込まずに液体だけをエンジンに供給するものであ る。これを地上で再現するのは難かしいが， $9 \mathrm{~m}$ の落下タワーを利用して，タンク内の液面の低重 力下での挙動を観測する実験を行った。図15はそ の一例で, 落下 0.84 秒後に液出口付近の液面が大 きく落ち込んだ状態を示しており，対策を講じな ければガスを吸込むが，出口付近にキャピラリ・ スクリーンを取付けて，ガスの吸込みを防止でき ることを確認した。

液体をタンク底部に集めるために，機体に推力 


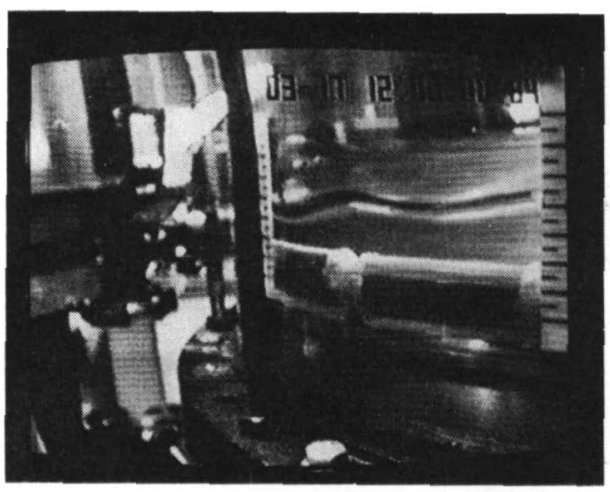

図15 低重力下での液吸込み実験

$1.8 \mathrm{~kg}$ のロケットを 4 個取付け, 1 回目の燃焼停 止後 100 秒間 4 基を作動させ て $0.003 \mathrm{G}$ の加速度 をかけたあと、1基の久を連続作動, さらに再着 火の前 120 秒間 4 基のロケットを作動させるよう にした。これにより，H-Iロケットは初号機で 再着火に成功した。

\section{5. エンジン開発のまとめ}

LE-5 エンジンの開発試験は昭和 53 年に始 り, 昭和60年に完了した。この間484回, 累計 35 , 564 秒の燃焼試験を実施した。エンジンの信頼度 をこの燃焼試験の結果から算出するのは難かし い。とくに開発過程のように，不具合を設計変更 によって解決しながら試験を行ら場合には, 初期 のエンジンと開発最終段階のエンジンが同一母集 団に属するとして単純に試験成功率を計算しても 意味はない。一つの試みとして

(1) 1 回 1 回の試験を不具合の有無で成功, 失敗 に分ける。

（2）燃焼時間が定格值より短い場合には, 試験回 数を 1 でなく，係数をかけて数㝋る。

（3）試験で何かの不具合があった場合には, 失敗 として数えるが，対策をとって不具合が再発 しないことが確認されれば，不具合要因が除 去されたとして，不具合を起こした試験を除

いて計算する。

等の考えで計算した結果を図16に示す。信頼度は 信頼水準を60\%として $99.52 \%$ となった。

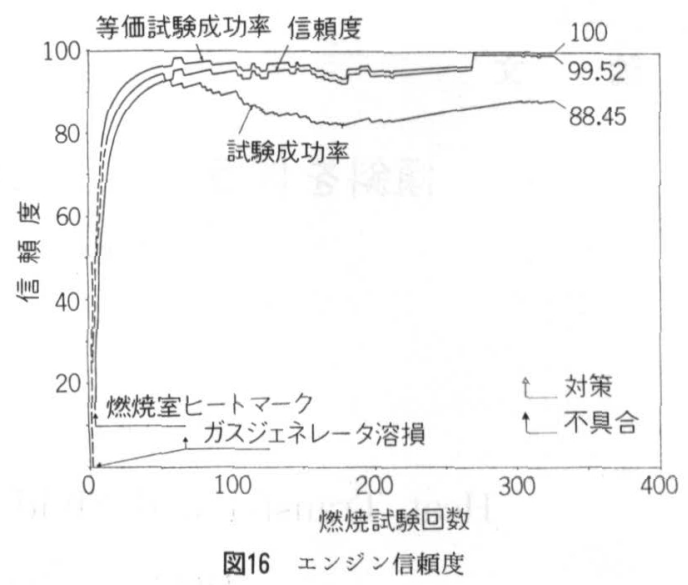

\section{6. まとめ}

LE-5 エンジンは比較的順調に，ほぼ計画 ど扰 りに開発できたプロジェクトである。その理由は いろいらあるが，第 1 は着実に開発ステップを踏 んで進めたことである。LE-5 の前に開発した LE -3 エンジンでは構想確認試験, 設計確 認試 験, 認定試験の 3 段階で進めたが，LE-5 エンジンで は，この前に基礎試験を入れて 4 段階の開発プロ グラムとしたことである。第 2 は開発が始まる前 に液体水素の試験設備を作り, 秋田県に燃焼試験 場を開発するなど, インフラストラクチャの整備 をしたことである。第 3 は海外に実例があったこ とで, 怙かげでかなりの設計データも入手でき, 確信をもって開発に当たることができた。

今, 国内でも, 将来のスペースプレーンをめざ した研究が始まっているが，これは海外でもまだ 実例がなく，どのような姿になるかもわかってい ないプロジェクトである。このため, LE-5 ×ン ジン以上に基礎的な研究を進め, そのためのイン フラストラクチャの整備も行わなければならない と考兄るので，とくに基礎的な研究に携って拈ら れる皆様のご支援を和願いしたい。

さいごに，LE-5 エンジンは宇宙開発事 業団, 航空宇宙技術研究所のご指導の下に石川島播麿重 工業株式会社と三菱重工業株式会社が共同で開発 したものであることを付記しておく。 